\title{
The Effect of the Dreamer Spiritual Therapies on Saliva Cortisol Hormone and Pain Score Patients in the Intensive Care Unit: A True-experimental Study
}

\author{
Iwan Purnawan ${ }^{1,2 *}$, Sri Setiyarini ${ }^{3}$, Probosuseno Probosuseno ${ }^{4}$, Yunita Widyastuti ${ }^{4}$ \\ ${ }^{1}$ Department of Nursing, Faculty of Health Sciences, Jenderal Soedirman University, Purwokerto, Indonesia; ${ }^{2}$ Doctoral Program in \\ Medical and Health Sciences, Faculty of Medicine, Public Health, and Nursing, Gadjah Mada University, Yogyakarta, Indonesia; \\ ${ }^{3}$ Department of Nursing, Faculty of Medicine, Public Health and Nursing, Gadjah Mada University, Yogyakarta, Indonesia; \\ ${ }^{4}$ Department of Medicine, Faculty of Medicine, Public Health and Nursing, Gadjah Mada University, Yogyakarta, Indonesia
}

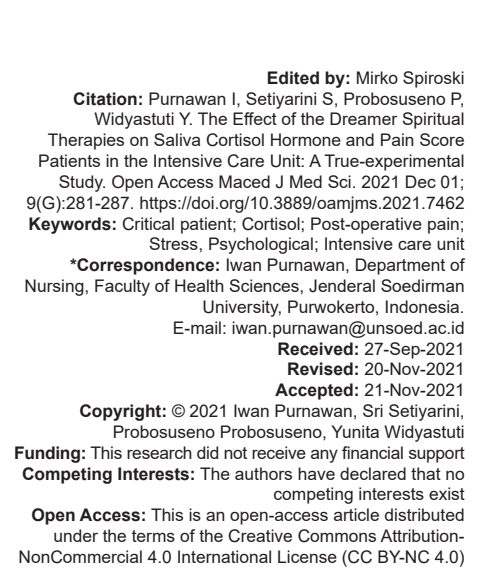

Abstract

BACKGROUND: Patients' conditions can worsen if stress and pain are not appropriately managed. Conventiona therapy ignores psychological and spiritual aspects. Both influence the body's response to various stimuli.

AIM: This study aimed to assess how Dreamer's spiritual therapy can affect the cortisol and pain in the intensive care unit (ICU) patients.

METHODS: It involved $86 \mathrm{ICU}$ patients in a true-experimental study. Respondents were divided into the intervention and the control group randomly. The intervention group received Dreamer spiritual therapy (DST) for 30 min but not for the control group. Saliva samples and pain scores were taken from both groups before and after treatment. The comparison of two groups cortisol decreases using Wilcoxon test. Differences in pre- and post-pain scores in each group were analyzed using paired t-test.

RESULTS: According to Levene's test, the two groups were homogeneous ( $p>0.05$ ). The Wilcoxon test revealed a statistically significant difference in cortisol level reduction between the intervention $(3.88 \mathrm{ng} / \mathrm{mL})$ and contro $(3.82 \mathrm{ng} / \mathrm{ml})$ groups $(p=0.024)$, with a large effect size (Cohen's $d$ value $=59.5)$. The paired t-test revealed a statistically significant decrease in the intervention group's pain score from 2.6 to $1.95(p=0.001)$, with a moderate effect size (Cohen's d value $=0.49$ ). The control group's pain score did not significantly decrease $(p=0.75)$.

CONCLUSIONS: A DST is effective in reducing salivary cortisol levels and pain scores of ICU patients.

\section{Introduction}

Stress and pain are the most often reported problems in patients admitted to the intensive care unit (ICU) [1]. This condition activates the sympathetic nervous system and results in release of stress hormones such as cortisol and aldosterone. Increased blood pressure, pulse rate, and blood vessel vasoconstriction can increase heart work and alter the patient's hemodynamics [2]. Unmanaged stress and pain impairs the healing process, exacerbates the complications, and prolongs the length of stay [3].

The management of stress and pain in ICU patients is not optimal yet. Until now, physical and psychological discomfort has persisted despite appropriate pain management in ICU patients [4]. It is hypothesized that managing stress and discomfort in ICU patients does not consider psychological or spiritual variables [2]. Psychological and spiritual factors impact pain in addition to nociceptive sensory sensations. Complementary and alternative medicine (CAM) includes all human qualities as holistic beings [1].
CAM is a valuable adjunct to conventional therapy in terms of addressing psychological and spiritual needs. When medical treatment is combined with CAM, synergy can occur, enhancing the effectiveness of the standard treatment [1], [2]. The difficulties associated with using CAM with the patients in the ICU are a lack of time and presence of therapists [2]. Nurses' motivation to provide spiritual assistance is limited due to their heavy workloads and time constraints [5]. As a result, a simple spiritual support model to the lower stress and discomfort in ICU patients is required.

Dreamer spiritual therapy (DST) is spiritual support in sound recordings of relaxing music, Koranic recitation (murottal), dhikr, and prayers. The term "Dreamer" is derived from various components, including dhikr, prayer, Al-Quran recitation, and music relaxation. DST is a form of sound therapy, as it uses sounds to produce a therapeutic effect. The use of sound therapy in the ICU is particularly ideal because it requires only a few simple tools (an MP3 player and headphones) and does not require any specific expertise staff [6], [7]. 
Comfort and self-transcendence are the two nursing theories underlying DST. The comfort theory focuses on the psychological, spiritual, and environmental components of well-being. Meanwhile, the concept of self-transcendence increases patients' internal qualities, such as transforming a negative perception into a positive one. Relaxing music and dhikr create a sense of tranquility, which can increases the levels of endorphin production. At the same time, prayer helps the limbic system turn negative thoughts into positive ones. This process is essential for limiting maladaptive stress responses that activates the stress hormones and sympathetic nervous system. Involvement of the limbic system in the therapeutic mechanism of DST is not found in conventional therapy [8], [9], [10], [11], [12], [13], [14].

The constituent elements of DST, such as relaxation music, murottal, dhikr, and prayer, in previous studies, have been shown to have a calming effect. Some of the therapeutic effects produced includes increasing release of endorphins [15], alleviates the level of pain [16], [17], [18], [19], [20], [21], alleviate anxiety [17], [18], [20], [21], and improves the quality of sleep [16], [20]. There has never been a study that has integrated relaxing music, dhikr, murottal, and prayer in a spiritual healing approach to date, especially for ICU patients. The aim of this study was to determine the effect of DST on salivary cortisol levels and pain in ICU patients.

\section{Methods}

Ethical approval of this study was obtained from the Medical and Health Research Ethics Committee of Gadjah Mada University-Dr Sardjito General Hospital, Yogyakarta, Indonesia, (No. KE/FK/1110/EC/2020). Margono Soekarjo Hospital, Purwokerto, Central Java Region, Indonesia, also approved this research (IRB No. 480/03896/IV/2021). This study was conducted following the Helsinki Declaration.

It is a true experimental design with a pre-and post-test control group. Randomization was used to determine whether a respondent was in the control or intervention group. Data collection was carried out from April to May 2021 at the ICU of Prof. Hospital. Margono Seokarjo Purwokerto, Central Java Regency, Indonesia.

ICU patients who met the inclusion criteria were >15 years old, Muslim, $24 \mathrm{~h}$ post-operative, hemodynamically stable, responsive to sound stimulation, and received family approval. They were excluded if they were taking norepinephrine $>0.1 \mathrm{mg} / \mathrm{kg}$, dopamine $>10 \mathrm{mg} / \mathrm{kg}$, or dobutamine $>10 \mathrm{mg}$. Sample calculations were performed using a sample calculation formula based on previous studies' mean and standard deviation the mean and standard deviation of cortisol in the control group $(1.3 \pm 0.1)$ and the treatment group
$(0.5 \pm 0.9)$ [22], [23]. The calculation results show that 36 respondents are needed for each group and 72 for the total number of respondents, assuming a dropout rate of $10 \%$. This study found 150 respondents who have the potential to become respondents. However, only 86 respondents met the inclusion and exclusion criteria, with 43 people in each group. The process of selecting patients as respondents is shown in Figure 1.

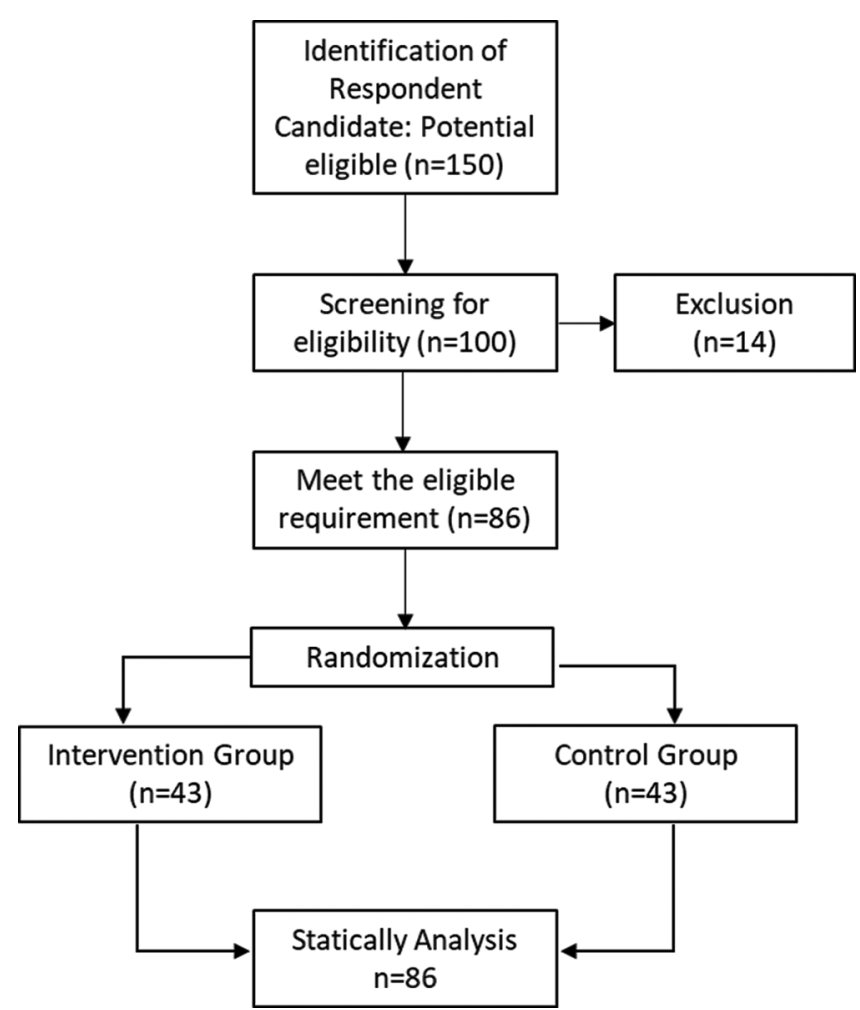

Figure 1: Respondent selection chart

Eligibility screening based on inclusion and exclusion criteria was performed for every patient admitted to the ICU. The informed consent process was carried out on patients eligible to obtain consent from the patient's family. If the family agrees, respondents get label numbers based on the order of arrival. The next stage of selecting respondents is a randomization to determine groups (intervention or control). Randomization was done using a table of random.

Data collection was carried out every 08.00 pm until $11.00 \mathrm{pm}$ because the body's cortisol levels are relatively stable [23], and many treatment procedures have been reduced. $10 \mathrm{~min}$ before treatment, respondents' gums and teeth were cleaned with an oral sponge moistened with distilled water. Saliva sampling as a pre-cortisol was carried out between 1 and 3 min before treatment. For $30 \mathrm{~min}$, the intervention group received DST through an MP3 player and earphones. The control group continued to receive standard therapy. 10, 20, and $30 \mathrm{~min}$ after treatment, criticalcare pain observation tool (CPOT) measurements were taken. 30 min after treatment, saliva samples as a postcortisol were collected.

For $30 \mathrm{~s}$, saliva was absorbed using paper points inserted between the teeth and gums. Paper 
points that have been filled with saliva were inserted into a $1.5 \mathrm{ml}$ Eppendorf vacuum containing phosphate buffer saline solution. Each tube was labeled according to the patient code. The saliva samples were frozen for later use. Cortisol levels in saliva were analyzed using an enzyme-linked immunosorbent assay (ELISA) technique. The machine used to analyze cortisol levels is the ELISA Reader Labotron LB-6200 made in Germany. The reagent used was Human Cortisol ELISA, which was produced by the Bioassay Technology Laboratory in China.

Table 1: Respondents clinical data

\begin{tabular}{|c|c|c|c|c|c|}
\hline \multirow[t]{2}{*}{ Characteristics } & \multicolumn{2}{|c|}{ Intervention group } & \multicolumn{2}{|c|}{ Control group } & \multirow[t]{2}{*}{$p$-value ${ }^{*}$} \\
\hline & $f$ & $\%$ & $f$ & $\%$ & \\
\hline \multicolumn{6}{|l|}{$\overline{\text { Age }}$} \\
\hline $\begin{array}{l}\text { Teenagers ( } 11-19 \text { years } \\
\text { old) }\end{array}$ & 1 & 2 & 4 & 9 & \multirow[t]{3}{*}{0.41} \\
\hline Adult (20-60 years old) & 28 & 65 & 29 & 67 & \\
\hline Elderly (>60 years old) & 14 & 33 & 10 & 23 & \\
\hline \multicolumn{6}{|l|}{ Gender } \\
\hline Male & 17 & 39.5 & 24 & 55.8 & \multirow[t]{2}{*}{0.43} \\
\hline Female & 26 & 60.5 & 19 & 44.2 & \\
\hline \multicolumn{6}{|l|}{ Ethnic group } \\
\hline Java & 39 & 90.7 & 41 & 95.3 & \multirow{3}{*}{0.48} \\
\hline Sundanese & 4 & 9.3 & 1 & 2.3 & \\
\hline Sumatra & 0 & 0 & 1 & 2.3 & \\
\hline \multicolumn{6}{|l|}{ Use of Mechanical Ventilators } \\
\hline Yes & 31 & 72.1 & 33 & 76.7 & \multirow[t]{2}{*}{0.33} \\
\hline No & 12 & 27.9 & 10 & 23.3 & \\
\hline \multicolumn{6}{|l|}{ Anesthesia type } \\
\hline General anesthesia & 39 & 90.7 & 40 & 93 & \multirow[t]{2}{*}{0.69} \\
\hline Regional anesthesia & 4 & 9.3 & 3 & 7 & \\
\hline \multicolumn{6}{|l|}{ Analgesic drug type } \\
\hline Opioid & 32 & 74.4 & 31 & 72.1 & \multirow[t]{2}{*}{0.69} \\
\hline Non-opioid & 11 & 25.6 & 12 & 27.9 & \\
\hline \multicolumn{6}{|l|}{ Giving analgesics } \\
\hline Continuous & 27 & 63 & 22 & 51 & \multirow[t]{3}{*}{0.19} \\
\hline Intermittent & 2 & 5 & 2 & 5 & \\
\hline Bolus & 14 & 33 & 19 & 44 & \\
\hline \multicolumn{6}{|l|}{ Anti-inflammatory drug use } \\
\hline Yes & 7 & 16.3 & 9 & 20.9 & \multirow[t]{2}{*}{0.523} \\
\hline No & 36 & 83.7 & 34 & 79.1 & \\
\hline
\end{tabular}

\section{Statistical analysis}

Continuous data were presented as mean or median, while categorical data were displayed as frequency. The Shapiro-Wilk test was used to check the normality of data. The significance of the differences in pre- and post-cortisol levels in each group was identified using the Mann-Whitney Test. At the same time, the Wilcoxon test was used to determine the difference in the decrease in cortisol levels between the intervention group and the control group. Paired t-test was used to determine differences in pain scores pre and post in intervention groups. Because the control group's pain score, data were not normally distributed, the difference between pre and post pain scores was done using the Mann-Whitney test. Cohen's d test was used to measure the effect size of DST on pain and cortisol levels. All statistical analyzes were performed using IBM SPSS version 20.

\section{Results}

Age, gender, use of mechanical ventilators, type of surgery, drug use (anesthesia, analgesics, and anti-inflammatory), and nutrition were all collected from the respondents. Table 1 contains a description of the respondents' clinical data.

According to Levene's test, both groups were homogeneous in terms of age, gender, mechanical ventilation use, type of anesthesia, analgesic, and anti-inflammatory medication. $p>0.05$ indicates this. Table 2 describes the duration of the operation, the time interval between study's conduct and the surgery/ anesthesia and administration of drugs.

Table 2 shows that the duration of surgery and the distance between surgery and the conduct of the study were homogeneous in both groups. The distance between the administration of analgesics, anesthetics, anti-inflammatory drugs, and nutrition and the conduct of the study was also homogeneous. This is indicated by $p>0.05$ in the Levene test. The Levene test revealed that the two groups were homogeneous in terms of medical diagnosis ( $p=0.342$ ). In both groups, the most common medical diagnosis was a brain tumor. It is seen in Figure 2.

Table 2: The interval time between surgery and medication to research conduct

\begin{tabular}{llll}
\hline Interval time & $\begin{array}{l}\text { Intervention } \\
\text { Median (range) }\end{array}$ & $\begin{array}{l}\text { Control } \\
\text { Median (range) }\end{array}$ & p-value \\
\hline Surgical duration (hour) & $2(1-7)$ & $2(0.5-8)$ & 0.287 \\
Surgical - study (hour) & $9(2-45)$ & $8.5(3.5-11.5)$ & 0.08 \\
Anesthesia drug - study (hour) & $11.5(3.5-46.5)$ & $11(3.5-13)$ & 0.106 \\
Analgesic drug - study (hour) & $0.00(0.0-5)$ & $0.00(0.0-5.5)$ & 0.189 \\
Nutrition - study (hour) & $0.00(0.0-3)$ & $0.00(0.0-3.5)$ & 0.523 \\
\hline$\left.{ }^{*}\right)=$ Levene test. & & &
\end{tabular}

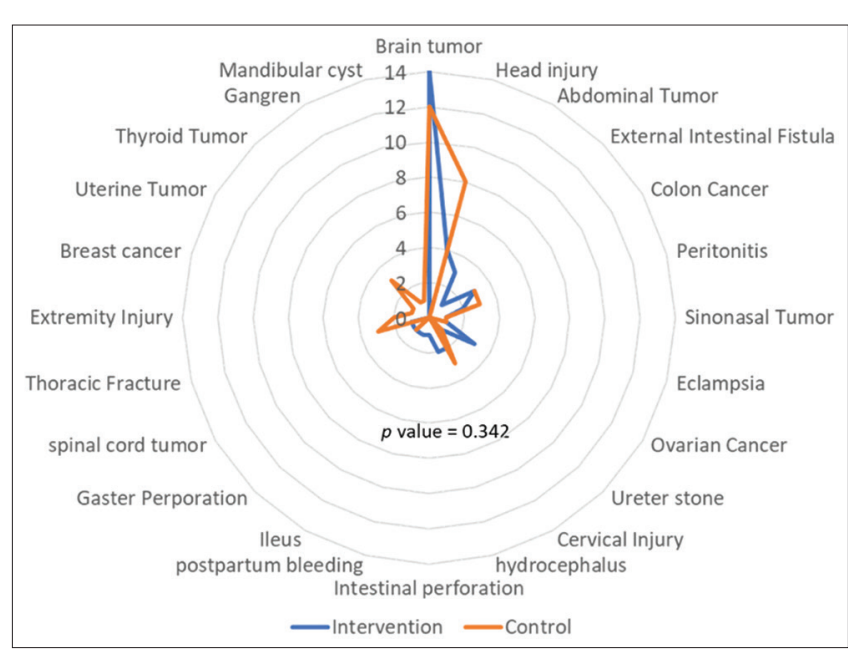

Figure 2: The respondent's medical diagnostic

With a high prevalence of brain tumors and head injuries, craniotomy is the most frequently performed type of surgery, as shown in Figure 3. Levene's test revealed that both groups were homogeneous in surgical type $(p=0.33)$.

Two statistical tests, Wilcoxon and MannWhitney, were used to determine the effect of DST on cortisol levels. Wilcoxon test was used to determine differences in pre and post salivary cortisol levels in each group. The Cohens one-group test was used to determine the effect size of the treatment in each group on cortisol levels. It is illustrated in Table 3. 


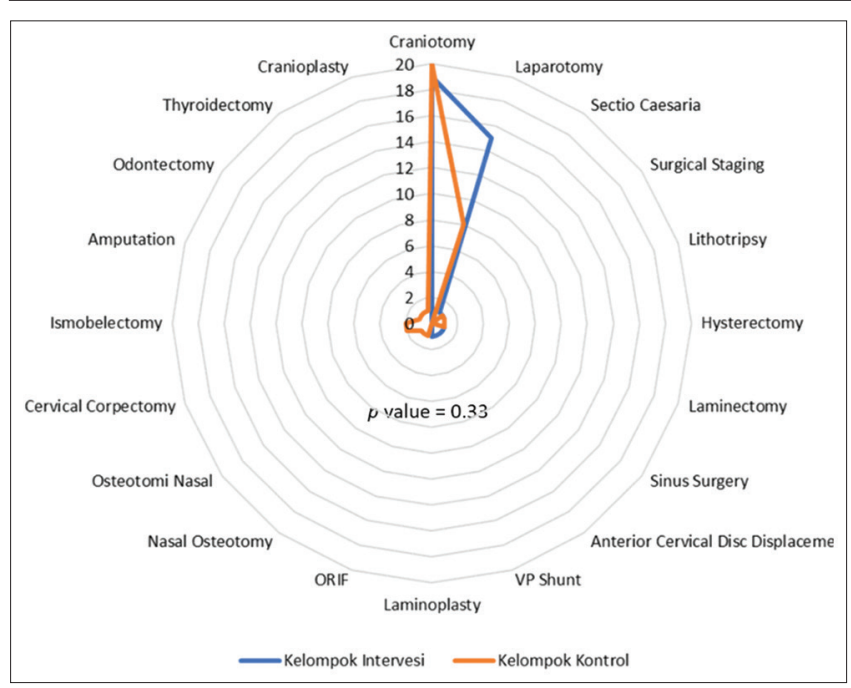

Figure 3: The respondent's surgical type

Table 3: Cortisol differences before and after treatment

\begin{tabular}{lllllll}
\hline Group & $\overline{\mathrm{x}}(\mathrm{SD})$ & $\Delta \overline{\mathrm{x}}$ & $\begin{array}{l}\text { Median } \\
(\text { Range })\end{array}$ & $\Delta \mathrm{m}$ & $\mathrm{p}$-value & $\mathrm{d}$-value \\
\hline $\begin{array}{l}\text { Intervention } \\
\text { group }\end{array}$ & & & & & & \\
$\quad \begin{array}{l}\text { Cortisol-Pre } \\
(\mathrm{n}=43)\end{array}$ & $16.2(10.2)$ & 7.4 & $12.5(9.09-49.41)$ & 3.6 & $<0.001^{\text {a) }}$ & $0.77^{\text {b) }}$ \\
$\quad \begin{array}{l}\text { Cortisol-Post } \\
(\mathrm{n}=43)\end{array}$ & $8.8(2.4)$ & & $8.9(3.17-15.79)$ & & & \\
$\begin{array}{l}\text { Control group } \\
\text { Cortisol-Pre } \\
(n=43)\end{array}$ & $12.1(2.4)$ & 8.8 & $12.1(7.56-18.74)$ & 9.3 & $<0.001^{\text {a) }}$ & $2.07^{\text {b) }}$ \\
$\begin{array}{l}\text { Cortisol-Post } \\
(n=43)\end{array}$ & $3.3(1.8)$ & & $2.8(0.23-8.42)$ & & & \\
\hline $\begin{array}{l}\text { SD: Standard deviation, a): Wilcoxon test, } \bar{x}: \text { Mean, } \Delta \bar{x}: \text { Mean difference, } \Delta m: \text { Median difference, d: Size } \\
\text { effect, b): Cohen's d one-group test. }\end{array}$
\end{tabular}

The Wilcoxon test indicates that both groups have a significant decrease in cortisol levels $(p<0.001)$. The d-value suggests that both DST and conventional therapy have a big size effect on cortisol levels reduction. The Mann-Whitney test was conducted to determine the difference in the magnitude of the decrease in cortisol levels between the two groups. The results of the Mann-Whitney test are presented in Table 4.

Table 4: Cortisol level reduction differences between intervention and control groups

\begin{tabular}{|c|c|c|c|c|c|c|}
\hline Group & $\overline{\mathrm{x}}(\mathrm{SD})$ & $\Delta \overline{\mathrm{x}}$ & $\begin{array}{l}\text { Median } \\
\text { (Range) }\end{array}$ & $\Delta \mathrm{m}$ & $\mathrm{p}$-value & d-value \\
\hline $\begin{array}{l}\text { Cortisol reduction in } \\
\text { the intervention group } \\
(\mathrm{ng} / \mathrm{ml})(\mathrm{n}=43)\end{array}$ & $7.3(9.1)$ & 5.00 & $\begin{array}{l}3.88 \\
(1.64-38.18)\end{array}$ & 1.06 & $0.024^{a)}$ & $59.5^{b)}$ \\
\hline $\begin{array}{l}\text { Cortisol reduction in } \\
\text { the control group (ng/ } \\
\mathrm{ml})(\mathrm{n}=43)\end{array}$ & $3.3(1.8)$ & & $2.82(0.23-8.42)$ & & & \\
\hline
\end{tabular}

The Mann-Whitney test results in Table 4 indicate a statistically significant difference in the decrease in cortisol levels between the two groups $(p=0.024)$. Cortisol levels decreased significantly more in the intervention group than in the control group. Cohen's $d$ test indicated that DST had a large effect size on cortisol reduction $(d=59.5)$.

\section{DST's effects on pain score}

Paired t-test was used to compare pain scores before and after therapy in the two groups.
Paired t-test results in the intervention group showed that the mean CPOT score decreased significantly $(p=0.001)$ from $2.60 \mathrm{ng} / \mathrm{ml}$ (pre) to $1.95 \mathrm{ng} / \mathrm{ml}$ (post), with a moderate effect size (value of $d=0.49$ ). The Wilcoxon test showed no significant difference between the median pain values of the control group before $(3 \mathrm{ng} / \mathrm{ml})$ and post $(2.6 \mathrm{ng} / \mathrm{ml})$. Based on this, DST has been shown to significantly reduce pain scores.

\section{Discussion}

The demographic characteristics of respondents, such as ethnic origin [24], age [25], and gender [26], [27], have an influence on stress, anxiety, and pain. Levene's test shows that the two groups of respondents (control and intervention) have homogeneous demographic characteristics $(p>0.05$. Thus, the possibility of bias in the research results due to differences in age, gender, and ethnicity can be prevented. Various medical procedures, such as surgery, mechanical ventilation, and side effects of drugs, can cause discomfort and stress to patients in the ICU [28], [29]. The effect of disease diagnosis on anxiety is related to disease severity [30].

The time interval between various procedures or drug administration to data collection can affect cortisol levels and pain scores. The larger the time interval, the less the effect on pain and cortisol levels [31], [32]. Cortisol, for example, will begin to decrease within 24-48 h after surgery [29]. Levene's test on all respondents' clinical data showed $p>0.05$. It showed that both groups of respondents have homogeneous clinical data. Thus, the bias in the results due to differences in clinical data in the two groups can be overcome.

Statistical analysis revealed that DST had a significant effect on cortisol levels and pain scores. Cortisol levels in both groups decreased significantly, as shown in Table 3. However, as shown in Table 4, the decrease in cortisol in the intervention group was more significant than in the control group with a large effect size. Likewise, a significant decrease in CPOT scores only occurred in the intervention group with moderate effect size, as shown in Table 5.

The decrease in cortisol levels in the control group was due to various drugs such as anesthetics, analgesics, and anti-inflammatory drugs [33], [34], [35]. It occurs due to the inhibitory mechanisms of central nervous system stressors, which reduce the stress response. Decreased cortisol levels are indicative of stress reduction through endocrine mechanisms [33]. However, lowering cortisol as a stress biomarker is not optimal because drugs only prevent brain stimulation by stressors. For example, general anesthesia can 
Table 5: Pre- and post-treatment differences in the pain score

\begin{tabular}{|c|c|c|c|c|c|c|}
\hline Group & (SD) & $\overline{\Delta \bar{x}}$ & $\begin{array}{l}\text { Median } \\
\text { (Range) }\end{array}$ & $\Delta \mathrm{m}$ & $p$-value & d-value \\
\hline \multicolumn{7}{|l|}{ Intervention group } \\
\hline Pre-pain score & $2.60(0.65)$ & 0.65 & $3(1-5)$ & 1 & $<0.001^{\text {a) }}$ & $0.49^{c)}$ \\
\hline Post-pain score & $1.95(0.67)$ & & $2(1-4)$ & & & \\
\hline \multicolumn{7}{|l|}{ Control Group } \\
\hline $\begin{array}{l}\text { Pre-pain score } \\
\text { Post-pain score }\end{array}$ & $\begin{array}{l}2.7(0.8) \\
2.5(0.96)\end{array}$ & 0.16 & $\begin{array}{l}3(1-5) \\
2.6(1-6)\end{array}$ & 0.4 & $0.75^{\mathrm{b})}$ & $0.11^{\mathrm{c})}$ \\
\hline
\end{tabular}

reduce the pain sensation associated with surgery but does not relieve the stress response. The hypothalamus continuously responds to unpleasant stimuli by releasing stress hormones. Even at more profound levels of anesthesia, this mechanism persists [36]. The large number of patients in the ICU who complain of discomfort despite receiving standard therapy is an example of this argument [4]. This mechanism also causes a decrease in pain scores in the intervention group are more significant than the control group.

Drugs can inhibit pain stimuli that enter the sensory center in the cerebral cortex. However, if an event creates a negative perception, then the discomfort is still there. Perceived threats stimulate the hypothalamus to release the hormone corticotropin-releasing factor (CRF). The CRF hormone then stimulates the anterior pituitary to secrete adrenocorticotropic hormone (ACTH). ACTH stimulates the adrenal cortex to generate cortisol [2]. Adverse psychological states such as anxiety and stress and elevated cortisol levels affect how a person perceives pain. In stressful situations and worry, a person's pain threshold decreases, making them more sensitive to pain [37], [38].

The decrease in cortisol levels and pain scores in the intervention group was due to DST and influenced by standard therapy. As a CAM, DST acts as a complement to standard therapy [38]. DST produces a synergistic effect with standard therapy through strengthening psychological and spiritual aspects. It causes a decrease in cortisol levels, and pain scores in the intervention group are more significant than the control group.

The DST mechanism in lowering cortisol and pain scores is based on two nursing theories: the theory of comfort and the theory of self-transcendence. The first theory highlights the critical role of calm and comfort in the healing process. The second theory emphasizes the importance of positive perceptions in the face of unpleasant stimuli [9]. The previous research has reinforced this theory. Listening to music can reduce the anxiety and cortisol levels of patients undergoing dental treatment [39].

Calmness and comfort both contribute significantly to the reduction of stress and pain. This condition triggers the hypothalamus to stimulate the anterior hypophysis to produce endorphins. This hormone, which has a morphine-like structure, inhibits pain perception, provides strength and confidence, and promotes feelings of well-being and happiness [39]. DST consists of several elements such as relaxation music, murottal, dhikr, and prayer. The constituent elements of DST in several previous studies can provide a pleasant effect and reduce pain in various cases and conditions. Several cases and conditions that have been studied include cancer pain [18], [40], [41], childbirth [42], hypertension [43], and hemodialysis [40]. Murottal, as one of the elements of DST, has also been shown to increase endorphin levels [15] during labor and decrease the need for opioids in post section caesarian [43].

The second mechanism of DST in dealing with stress and pain is through spiritual content that provides motivation and positive perception. It refers to how the amygdala responds to various incoming stimuli. Negative perceptions trigger maladaptive reactions, which include releasing stress hormones and activation of the sympathetic nervous system. Meanwhile, a positive perception of the incoming stimulus produces an adaptive response that induces a state of relaxation and increases the production of endorphins [29], [44], [45].

DST is involved in the process by which the incoming stimulus is perceived. Spiritual content elicits memories about the meaning of every event he encounters, including his current illness, from the hippocampus. This therapy assists patients in transforming negative perceptions about the pain and illness they are experiencing into positive ones. When accepted with sincerity, a Muslim believes that every illness, sadness, or suffering will wash away his sins. In addition, this therapy can help respondents improve their perceptions of their illness. Prayer is a critical component of DST because it enables him to develop the confidence necessary to confront life's difficulties [45].

Positive perceptions created in the prefrontal cortex activate the adaptive reactions in the amygdala and avoid maladaptive reactions. The adaptive response of the amygdala occurs when the incoming input from the prefrontal cortex is positive and deemed innocuous. This adaptive reaction is characterized by a relaxed state of mind and a sense of well-being. This condition may lead to a decrease in stress hormones such as adrenaline, noradrenaline, glucocorticoids, and cortisol. The hypothalamus will then direct the anterior pituitary to release endorphins, promoting happiness and blocking unpleasant stimuli [45]. Listening to murottal and prayer can reduce anxiety in hemodialysis patients [44] and increase levels of the hormone endorphins in women giving birth [15].

\section{Conclusions}

The intervention group receiving DST shows significant reduction in the cortisol levels and CPOT 
scores than the control group. DST does not harm ICU patients, so it is safe to use as a complementary and alternative therapy in the ICU.

\section{Acknowledgments}

We thank to the ICU nursing staff of Prof Margono Soekarjo Purwokerto Hospital, who has helped a lot during the research process. We would also thank to Jenderal Sudirman University and the Doctoral Program in Medicine and Health Sciences, Gadjah Mada University, for providing opportunities and support during the research process.

\section{References}

1. Klein DG, Dumpe M, Katz E, Bena J. Pain assessment in the intensive care unit: Development and psychometric testing of the nonverbal pain assessment tool. Hear Lung J Acute Crit Care. 2010;39(6):521-8. https://doi.org/10.1016/j.hrtlng.2010.05.053 PMid:20888642

2. Urden LD, Stacy KM, Lough ME. Critical Care Nursing : Diagnosis anda Management. $7^{\text {th }}$ ed. Canada: Mosby; 2014.

3. Puntillo M. Pain. In: Pathophysiological Phenomena in Nursing: Human Responses to Illness. $3^{\text {rd }}$ ed. Carrieri-Kohlman, Lindsey. St. Louis, Missouri: Saunders; 2003. p. 235-55.

4. Berntzen H, Bjørk IT, Wøien H. Pain relieved, but still strugglingcritically ill patients experiences of pain and other discomforts during analgosedation. J Clin Nurs. 2018;2(1):223-34. https:// doi.org/10.1111/jocn.13920

PMid:28618123

5. Ristianingsih D, Septiwi C, Yuniar I. An overview of nursing motivation and actions in fulfilling patient spiritual needs in the ICU PKU muhammadiyah. Kesehatan. 2014;10(2):100-7.

6. Al-Kaheel A. Al Qur'an the Healing Book. Jakarta: Tarbawi Press; 2011.

7. Kozier B, Erb G, Berman A, Snyder S. Kozier and erb's fundamentals of nursing: Concepts, process and practice. Nurse Educ Pract. 2012;12(2):e12. https://doi.org/10.1016/j. nepr.2011.09.002

8. Alligood MR, editor. Nursing Theorist and Their Work. $8^{\text {th }}$ ed. St. Louis, Missouri: Elsevier; 2014. p. 765.

9. Smith MJ, Liehr P, editors. Middle Range Theory for Nursing. New York: Springer Publishing Company; 2014. p. 479.

10. Hu R, Jiang $X$, Zeng $Y$, Chen $X$, Zhang $Y$. Effects of earplugs and eye masks on nocturnal sleep, melatonin and cortisol in a simulated intensive care unit environment. Crit Care. 2010;14(2):2-9. https://doi.org/10.1186/cc8965 PMid:20398302

11. Wallace J, Robins J, Alvord LS, Walker JM. The effect of earplugs on sleeo measures during exposure to stimulated ICU noise. Am J Crit Care. 1999;8(4):210-9. https://doi.org/10.4037/ ajcc1999.8.4.210

PMid: 10392220

12. Najafi Ghezeljeh T, Mohades Ardebili F, Rafii F. The effects of massage and music on pain, anxiety and relaxation in burn patients: Randomized controlled clinical trial. Burns. 2017;43(5):1034-43. https://doi.org/10.1016/j. burns.2017.01.011 PMid:28169080

13. Newberg AB, Wintering NA, Yaden DB, Waldman MR, Reddin J. A case series study of the neurophysiological effects of altered states of mind during intense Islamic prayer. J Physiol Paris. 2015;109(4-6):214-20. https://doi.org/10.1016/j. jphysparis.2015.08.001 PMid:26296991

14. Syarif M. Peranan do'a dan zikir dalam menghadapi trauma yang dialami pasien di rumah sakit 1. In: Seminar and Workshop Post Traumatic Counseling. Padang; EST; 2012. p. 147-55.

15. Wahida S, Nooryanto M, Andarini S. Al Qur'an Surah arrahman recital therapy increase $\beta$-endorphin levels and reduce childbirth pain. J Kedokt Brawijaya. 2015;28(3):213-6. https://doi. org/10.21776/ub.jkb.2015.028.03.9

16. Misnawati W, Ropyanto CB. In: Utami RS, editor. The Effect of Dzikir Concerning to Pain Level After Surgical Operation Reduction Internal Fixation (ORIF). Semarang: Harmony of Caring and Heali; 2015.

17. Rahman FS, Yahya N, Din NM, Izaham A, Mat WR. The comparative effects of listening to prayer recitation and music therapy intraoperatively on postoperative pain. Int Med J Malaysia. 2018;17(2):107-15. https://doi.org/10.31436/imjm. v17i2.277

18. Sulistyawati RA, Probosuseno, Setiyarini S. Dhikr therapy for reducing anxiety in cancer patients. Asia Pac J Oncol Nurs. 2017;4(2):95-7. https://doi.org/10.4103/apjon.apjon_33_19

19. Sukarni S, Mardiyono M, Parwati MD. 4T Zikr in anxiety reduction in acute coronary syndrome patients. J Ris Kesehat. 2014;3(2):567-75.

20. Jafari $H$, Zeydi AE, Khani S, Esmaeili R, Soleimani A. The effects of listening to preferred music on pain intensity after open heart surgery. Iran J Nurs Midwifery Res. 2012;17(1):1-6. PMid:23493927

21. Oktora SP, Purnawan I, Achiriyati D. The effect of murottal Al Qur'an therapy on sleep quality in the social rehabilitation unit of the dewanata cilacap. J Keperawatan Soedirman. 2016;11(3):168-73. https://doi.org/10.20884/1. jks.2016.11.3.710

22. Atiyaningsih N, Wulandari I. Dhikr Therapy to Improving Sleep Quality for Post Surgery Patient at Banten Indonesia. Indonesia: The $5^{\text {th }}$ AASIC; 2017.

23. Steptoe A, Serwinski B. Cortisol Awakening Response. Stress: Concepts, Cognition, Emotion, and Behavior: Handbook of Stress. Netherlands: Elsevier Inc.; 2016. p. 277-83. https://doi. org/10.1016/b978-0-12-800951-2.00034-0

24. Sussex R. How Different Cultures Experience and Talk about Pain. The Conersation; 2015. p. 11-3. Available from: https:/ www.theconversation.com/how-different-cultures-experienceand-talk-about-pain-49046. [Last Accessed on 2021 Aug 25].

25. Riley JL, Cruz-Almeida Y, Glover TL, King CD, Goodin BR, Sibille KT, et al. Age and race effects on pain sensitivity and modulation among middle-aged and older adults. J Pain. 2014;15(3):272-82. https://doi.org/10.1016/j.jpain.2013.10.015 PMid:24239561

26. El Tumi H, Johnson MI, Dantas PB, Maynard MJ, Tashani OA Age-related changes in pain sensitivity in healthy humans: A systematic review with meta-analysis. Eur J Pain (United Kingdom). 2017;21(6):955-64. https://doi.org/10.1002/ ejp.1011

PMid:28230292

27. Vellyana D, Lestari A, Rahmawati A. Faktor-Faktor yang Berhubungan dengan Tingkat Kecemasan pada Pasien Preoperative di RS Mitra Husada Pringsewu. J Kesehat. 
2017;8(1):108. https://doi.org/10.26630/jk.v8i1.403

28. Jacq G, Melot K, Bezou M, Foucault L, Courau-Courtois J, Cavelot $\mathrm{S}$, et al. Music for pain relief during bed bathing of mechanically ventilated patients: A pilot study. PLoS One. 2018;13(11):e0207174.

29. Annesi SM, Brooks-Brunn JA, Byers JF, Casey PE, Cash J, Corbin J. Brunner and Suddarth's Textbook of Medical-surgical Nursing. $14^{\text {th }}$ ed., Vol. 79. United States: Lippincott Williams \& Wilkins; 2017. p. 151.

30. Youssef NA, Abdelmalek MF, Binks M, Guy CD, Omenetti A, Smith $A D$, et al. Associations of depression, anxiety and antidepressants with histological severity of nonalcoholic fatty liver disease. Liver Int. 2013;33(7):1062-70. https://doi. org/10.1111/liv. 12165

PMid:23560860

31. Trevor AJ, White PF. Anestetik umum. In: Katzung BG, editor. Farmakologi Dasar dan Klinik. 10 $0^{\text {th }}$ ed. Jakarta: EGC; 2010. p. 405-85.

32. Hsu CC, Chen WM, Chen SR, Tseng YT, Lin PC. Effectiveness of music listening in patients with total knee replacement during CPM rehabilitation. Biol Res Nurs. 2016;18(1):68-75. https://doi. org/10.1177/1099800415572147

PMid:25693577

33. Waldron NH, Jones CA, Gan TJ, Allen TK, Habib AS. Impact of perioperative dexamethasone on postoperative analgesia and side-effects: Systematic review and meta-analysis. $\mathrm{Br} \mathrm{J}$ Anaesth. 2013;110(2):191-200. https://doi.org/10.1093/bja/ aes431

\section{PMid:23220857}

34. Koh IJ, Chang CB, Lee JH, Jeon YT, Kim TK. Preemptive low-dose dexamethasone reduces postoperative emesis and pain after TKA: A randomized controlled study. Clin Orthop Relat Res. 2013;471(9):3010-20. https://doi.org/10.1007/ s11999-013-3032-5

PMid:23645340

35. Irawan H. Perbandingan kadar kortisol dan efek analgesia pascabedah anestesi spinal kombinasi bupivakain hiperbarik 0 , $5 \% 8 \mathrm{mg}$ dan klonidin $30 \mu \mathrm{g}$ dengan bupivakain hiperbarik 0, 5\% $8 \mathrm{mg}$ dan Morfin 0, $1 \mathrm{mg}$ pada pasien yang menjalani prosedur seksio sesaria. Maj Anest dan Crit Care. 2017;32(2):111-7. https://doi.org/10.47507/obstetri.v3i2.45

36. Ozgocer T, Ucar C, Yildiz S. Cortisol awakening response is blunted and pain perception is increased during menses in cyclic women. Psychoneuroendocrinology. 2017;77:158-64. https://doi.org/10.1016/j.psyneuen.2016.12.011 PMid:28064085

37. Liu Y, Petrini MA. Effects of music therapy on pain, anxiety, and vital signs in patients after thoracic surgery. Complement Ther Med. 2015;23(5):714-8. https://doi.org/10.1016/j. ctim.2015.08.002

PMid:26365452

38. Dossey BM, Keegan L, Guzzetta CE. Holistic Nursing: A handbook for Practice. $4^{\text {th }}$ ed. London: Jones And Bartlett Publishers; 2013.

39. Mejía Rubalcava C, Alanís Tavira J, Mendieta Zerón H, Sánchez Pérez L. Changes induced by music therapy to physiologic parameters in patients with dental anxiety. Complement Ther Clin Pract. 2015;21(4):282-6. https://doi.org/10.1016/j. ctcp.2015.10.005

PMid:26573456

40. Rokade PB. Release of endomorphin hormone and its effects on our body and moods : A review. Int Conf Chem Biol Environ Sci. 2011;431127(215):436-8.

41. Mulyani NS, Purnawan I, Upoyo AS. Differences in effects of murottal therapy for 15 minutes and 25 minutes on reduction of pain scale in post-surgery cancer patients. J Bionurs. 2019;1(1):77-88.

42. Bayrami R, Ebrahimipour $\mathrm{H}$. Effect of the Quran sound on labor pain and other maternal and neonatal factors in nulliparous women. J Res Health Soc Dev Heal Promot Res Cent. 2014;4(4):898-902.

43. Wirakhmi IN, Novitasari D, Purnawan I. Comparison of influence of listening mozart music with murotal al quran on pain in hypertension patients. J Keperawatan Soedirman. 2018;13(3):100-6. https://doi.org/10.20884/1.jks.2018.13.3.813

44. Alivian GN, Purnawan I, Setiyono D. The effectiveness of listening to murottal and prayer to reduce anxiety in hemodialysis patients. J Keperawatan Sriwij. 2019;6(2):13-7.

45. Ahsan A, Khan M. The healing power of prayer in Islam. Indian J Posit Psychol. 2012;3(2):2012. 